\title{
PENGEMBANGAN KEMAMPUAN MUSIKALITAS GURU DI TK PANTI DEWI BERBAH SLEMAN
}

\author{
Francisca Xaveria Diah K. dan Yunike Juniarti Fitria \\ Fakultas Bahasa dan Seni, UNY \\ E-mail: diah_kristianingsih@uny.ac.id dan yunike_jf@uny.ac.id
}

\begin{abstract}
Abstrak
Penelitian ini bertujuan untuk membantu proses pengembangan kemampuan musikalitas guru di TK Panti Dewi Berbah Sleman sehingga kemampuan guru dalam bernyanyi dan mengiringi menjadi lebih optimal. Penelitian dilaksanakan bulan April sampai November 2017 menggunakan metode penelitian tindakan, dengan prosedur perencanaan, pelaksanaan, penilaian hasil, dan refleksi. Hasil penelitian menunjukkan bahwa kemampuan musikalitas guru semakin berkembang. Hal ini tampak pada hasil penilaian mendapat kategori baik meliputi kemampuan dasar bernyanyi dengan komponen artikulasi, intonasi dan ritmis, serta kemampuan dasar mengiringi dengan komponen harmoni akord, irama, dan tangga nada. Dengan cara melatih guru memahami membaca notasi musik, peka terhadap nada, irama dan tempo serta mengiringi lagu menggunakan keyboard, tindakan ini telah berhasil membantu guru di TK Panti Dewi dalam mengembangkan dan meningkatkan kemampuan musikalitasnya.
\end{abstract}

Kata kunci: pengembangan, kemampuan musikalitas, guru

\section{DEVELOPMENT OF TEACHERS' MUSICAL ABILITY IN KINDERGARTEN PANTI DEWI BERBAH SLEMAN}

\begin{abstract}
This study aims to assist the process of the development of teachers' musical ability in kindergarten Panti Dewi Berbah Sleman so that the ability of teachers in singing and accompanying to be more optimal. The study was conducted from April to November 2017 using action research method, with planning procedures, implementation, results assessment and reflection. The results showed that the teachers' musical abilities were growing. It can be seen from the result that it was categorised as good category in the basic ability to sing with articulation, intonation and rhythmic components and basic ability to accompany with chord, rhythm and cadence harmony components. Through training, teachers understand how to read music notes, sensitive to tone, rhythm, and tempo and use the keyboard while singing, this action has successfully helped teachers at Panti Dewi Kindergarten in developing and improving their musical ability.
\end{abstract}

Keywords: development, musical ability, teachers

\section{PENDAHULUAN}

Menjadi guru Taman Kanak-Kanak (TK) bukanlah suatu profesi yang mudah dilakukan. Seringkali orang hanya melihat guru TK setiap hari hanya mengajarkan bernyanyi, bercerita, mewarnai, menggambar dan beberapa permainan. Kemampuan atau kompetensi yang dimiliki guru TK kelihatan seperti hanya "setengah-setengah" atau seadanya. Sebagai contoh, guru TK harus bisa bernyanyi, tetapi bernyanyinya baik atau kurang baik, tidak dianggap sama sekali. Sering yang terjadi adalah 
guru TK mengajak anak didik bernyanyi tetapi nadanya "fals". Ada pula guru TK yang bisa mengiringi lagu menggunakan keyborad, tetapi iringan yang dimainkan tidak sesuai dengan irama atau harmoisasi lagu yang dimainkan.

Taman Kanak-Kanak Panti Dewi beralamat di Komplek TRP Tanjungtirto Berbah Sleman, terdiri atas 4 kelas TK dan 1 kelas PAUD. Guru di sekolah TK ini ada 10 orang dan semuanya perempuan. Ada tiga materi pembelajaran atau kegiatan yang berhubungan dengan seni musik yaitu bernyanyi, drumband dan menari. Materi bernyanyi dilaksanakan setiap upacara bendera pada hari Senin dan pada awal pembelajaran setiap harinya. Materi drumband dan menari diberikan pada hari tertentu sesuai jadwal masing-masing kelas. Pada setiap kegiatan ini, 10 orang guru tersebut semuanya terlibat, kecuali menari hanya beberapa guru saja.

Dilihat dari setiap memberikan materi pembelajaran atau kegiatan, kemampuan musikalitas guru di TK ini masih belum optimal. Para guru tersebut memberi contoh dalam bernyanyi, namun masih belum dapat merasakan bahwa nada yang dinyanyikannya kurang pas. Demikian pula saat seorang guru mengiringi lagu Indonesia Raya, Mengheningkan Cipta dan lagu pilihan pada saat upacara, irama dan harmonisasi lagu kurang selaras. Hanya saja ada hal lain yang menjadi kelebihan, yaitu beberapa guru dapat membuat dan menciptakan lagu yang sekali waktu dinyanyikan bersama para anak didik. Di antara para guru sendiri lagu ciptaan tersebut dilatihkan sebelum diberikan kepada para anak didik. Apabila ada kegiatan tertentu seperti kunjungan ke sebuah tempat, beberapa guru secara spotan membuat lagu yang berhubungan dengan kegiatan tersebut. Uniknya lagi lagu-lagu tersebut hanya dihafalkan syair dan nadanya tetapi belum ada yang tertulis sesuai dengan kaidah musiknya.

Pada pembelajaran drumband, guru ikut serta memberi aba-aba melatih ritmis dan melodi, tetapi terkadang berjalan sendiri tidak sesuai dengan apa yang diberikan oleh pelatih drumband yang sebenarnya. Demikian juga, saat menari atau senam pagi, gerakan yang ada tidak sesuai dengan hitungan atau ketukan pada iringan musiknya.
Kemampuan adalah suatu kesanggupan dalam melakukan sesuatu (KBBI, 1994:623). Poerwadarminta (1966:571) mengartikan kemampuan sebagai kesanggupan, kecakapan dan kekayaan. Semiawan (1984:1) menyatakan bahwa kemampuan merupakan suatu daya untuk melakukan tindakan sebagai hasil dari pembawaan dan latihan. Menurut Winkel (1986:26) kemampuan belajar merupakan kemampuan untuk berhasil dalam studi di jenjang pendidikan tertentu. Musikalitas berhubungan dengan individu yang memiliki rasa dalam musik secara khusus dan mendalam, serta tanpa disadari.

Hallam dan Prince (2003: 2-22), memandang cakupan musikalitas cukup luas, diantaranya mengenai pemahaman musikal, apresiasi, improvisasi, dan kepekaan yang baik pada ritme dan pitch/tinggi rendah nada. Meskipun demikian, namun tiap-tiap individu memiliki perbedaan dalam kepekaan akan musik, seperti yang dikemukakan oleh Müllensiefen (2014) dalam artikel jurnal berjudul "The Musicality of Non-Musicians: An Index for Assessing Musical Sophistication in the General Population". Müllensiefen menyebutkan bahwa kemampuan untuk merasakan dan memahami musik merupakan kemampuan manusia yang unik dan berbeda-beda. Kemampuan musikalitas juga dipengaruhi oleh perbedaan budaya pada masyarakat dan latar belakang pengalaman musikalnya. Dengan mengamati hal tersebut, maka dilakukan penelitian berkaitan dengan pengembangan musikalitas guru di TK Panti Dewi, sesuai dengan bidang profesi dan kompetensi guru Taman Kanak-Kanak.

\section{METODE}

Penelitian ini menggunakan metode pendekatan penelitian tindakan. Pemilihan pendekatan ini dilakukan karena penelitian bersifat praktis dan langsung relevan untuk situasi aktual. Selain itu, penelitian tindakan bersifat fleksibel dan adaptif dengan membolehkan perubahan guna mengembangkan keterampilan baru atau cara pendekatan baru untuk memecahkan masalah (Suryabrata, 2013:94). Dalam penelitian tindakan, peneliti 
terjun langsung dan melibatkan diri selama proses kegiatan pengembangan musikalitas berlangsung dan diikuti secara terus-menerus.

Penelitian dilaksanakan di TK Panti Dewi Komplek TRP Tanjungtirto Berbah Sleman, dimulai pada bulan April untuk kegiatan pralapangan berupa observasi, dan dilanjutkan dengan proses tindakan serta penilaian sampai bulan November 2107, dengan 10 orang guru sebagai subjeknya.

\section{Tahapan Penelitian}

1. Perencanaan

Pada tahap ini, peneliti menyusun skenario proses pengembangan kemampuan musikalitas, menyiapkan instrumen pengumpulan data, perangkat dan simulasi tindakan.

a. Menetapkan waktu pelaksanaan penelitian hari dan jam kegiatan.

b. Mempersiapkan guru TK Panti Dewi untuk diteliti dengan komunikasi pendahuluan melalui Kepala Sekolah TK Panti Dewi.

c. Menentukan materi pengembangan kemampuan musikalitas terdiri atas bernyanyi dan mengiringi. Untuk bernyanyi terdiri atas etude atau latihan khusus vokal yang diambil dari materi Concone Op.9 No. 1 dan No. 3, lagu Pemandangan, Serumpun Padi, Suwe Ora Jamu, Sarinande dan Gundul-Gundul Pacul, sedangkan untuk materi mengiringi lagu Lagu Indonesia Raya, Mengheningkan Cipta, Bendera Merah Putih, Satu Nusa Satu Bangsa, Ibu Kita Kartini, Kasih Ibu, Mars TK Panti Dewi, Kodok Ngorek, Pelangi dan Lihat Kebunku.

d. Menyiapkan instrumen observasi dengan komponen yang diamati adalah pada saat guru memberi contoh bernyanyi anak-anak di dalam kelas dan guru yang mengiringi pada waktu upacara bendera.

2. Pelaksanaan Tindakan

Tahap ini adalah tahap pelaksanaan tindakan berdasarkan rencana yang telah dibuat dan disiapkan. Pelaksanaan tindakan ini mengacu pada proses kegiatan guru dalam mengembangkan kemampuan musikalitas. a. Menyampaikan tujuan kegiatan dan materi yang diberikan.

b. Menjelaskan materi bernyanyi dan mengiringi, yang meliputi 3 latihan pokok yaitu (1) latihan untuk membaca dan memahami notasi musik, (2) latihan kepekaan terhadap nada, irama dan tempo, dan(3) latihan mengiringi lagu menggunakan keyboard.

c. Mendemonstasikan materi bernyanyi dan mengiringi sebelum para guru mempraktikkannya baik secara kelompok maupun individu.

d. Melatih guru dalam bernyanyi dan mengiringi secara berkelompok ataupun individu.

e. Mengamati aktivitas proses latihan guru dalam bernyanyi dan mengiringi.

f. Guru menampilkan hasil latihan bernyanyi saat di dalam kelas dan mengiringi saat upacara bendera.

g. Memberikan penilaian terhadap proses dan hasil bernyanyi dan mengiringi secara individu.

\section{Observasi}

Observasi dilakukan untuk mengamati proses dan dampak yang dihasilkan dari pelaksanaan tindakan. Pada pengamatan ini akan dicatat berbagai kejadian yang ada di sekolah berkaitan dengan proses kegiatan pengembangan kemampuan musikalitas, yang kemudian dijadikan sebagai data penelitian. Kegiatan observasi adalah mengamati perilaku dan respon guru terhadap materi pengembangan kemampuan musikalitas yang diberikan. Dalam hal ini apakah melalui bernyanyi dan mengiringi, kemampuan musialitas guru TK semakin berkembang.

\section{Refleksi}

Tahap refleksi didahului dengan kegiatan evaluasi. Dari hasil evaluasi ini akan ditemukan jawaban atas berbagai pertanyaan penelitian, yang kemudian menjadi acuan informasi untuk menentukan langkah penelitian berikutnya. Dalam hal ini hasil refleksi yang ingin diperoleh adalah bagaimana respon guru terhadap materi 
yang diberikan dan bagaimana manfaat yang diperoleh berkaitan dengan cara mengajar guru selanjutnya di dalam kelas. Pada latihan dan mengiringi saat upacara bendera sering terjadi kesalahan baik itu lupa akan posisi, melodi lagu dan progresi akord. Dalam hal ini peneliti langsung memberikan evaluasi dan selanjutnya guru yang akan bertugas di upacara berikutnya mempersiapkan diri sebaik-baiknya.

Pengumpulan data dilakukan dengan observasi, catatan harian, wawancara dan dokumentasi visual. Komponen yang diobservasi adalah proses guru memberi materi bernyanyi di dalam kelas kepada anak didik dan bagaimana guru mengiringi lagu pada waktu upacara. Catatan harian digunakan untuk mencatat kejadian yang berlangsung selama tatap muka dan besar kecilnya kendala yang dihadapi selama proses kegiatan. Tatap muka dilakukan secara kelompok maupun individu dan selama proses ini dibuatlah catatan, terutama saat terjadi dialog antara guru dan peneliti. Catatan ini kemudian menjadi bahan pertimbangan bagi perencanaan tindakan berikutnya.

Wawancara dilakukan di sekolah. Wawancara dilakukan secara tak terencana dan terencana tetapi tidak terstruktur guna menggali informasi yang lebih jelas tanpa mempengaruhi respon dan prilaku guru selama proses kegiatan. Wawancara dilakukan bersamaan dengan proses latihan individu dan saat pemberian materi yang dilakukan secara kelompok. Dokumentasi visual merupakan teknik pengumpulan data dengan mengamati objek penelitian dan merekam objek tersebut sehingga rekaman dapat menjadi alat bantu dalam proses penelitian. Dokumen ini berupa foto dan video kegiatan di sekolah, yaitu pada saat guru diberikan dan dijelaskan tentang materi, proses tanya jawab, kegiatan praktik atau demonstrasi, serta latihan mandiri dan wawancara kepada guru.

Instrumen Penelitian terdiri atas observasi kegiatan di sekolah dan penilaian praktik guru. Penilaian meliputi kemampuan dasar, bernyanyi dan mengiringi. Kategori penilaian adalah Sangat Baik $(<81)$, Baik $(71-80)$, Cukup $(61-70)$ dan Kurang $(>60)$. Kisi-kisi pertanyaan wawancara adalah : apakah guru memberi contoh murid bernyanyi, lagu apa saja yang sering diberikan, bagaimana cara guru mengajarkan lagu kepada murid, apakah guru bisa memainkan alat musik, dan berapa lama guru belajar tentang musik. Teknik analisis data dilakukan dengan analisis kualitatif dengan mendeskripsikan hasil kegiatan pengembangan musikalitas guru TK Panti Dewi. Validitas data yang digunakan meliputi beberapa hal. 1) Validitas proses yang dicapai dengan pengamatan pelaksanaan tindakan yang dilakukan dari awal sampai akhir proses pengembangan. Dalam hal ini yang pada awalnya guru masih minim dengan pengetahuan membaca dan memahami notasi musik, diakhir pertemuan sudah mulai dapat bernyanyi dengan baik, serta pada awalnya guru belum bisa memainkan alat musik keyborad, setelah diberi tindakan mulai dapat mengiringi dengan baik pula. 2) Validitas hasil diperoleh dari tindakan. Rata-rata setelah diberi latihan dengan materi bernyanyi, para guru mengalami peningkatan nilai di kemampuan dasar pada nada, ritmis dan tempo saat mengiringi. 3) Validitas demokratik dan validitas dialogik dilakukan sekaligus dan diperoleh melalui diskusi untuk memecahkan masalah yang dihadapi para guru selama kegiatan. Dalam hal ini guru berkonsultasi dengan peneliti bagaimana dapat mempraktikkan materi yang diberikan secara baik dan benar. Sementara itu, diantara para guru sendiri saling mengoreksi dan saling mengajari ketika ada guru yang melakukan kesalahan dan kekurangan saat mempraktikkan materi yang diberikan. Dalam hal ini baik peneliti maupun para guru samasama melakukan refleksi. Validitas instrumen yang digunakan adalah validitas isi. Validitas ini digunakan untuk mengukur kemajuan belajar dalam hal ini apakah yang sudah diketahui dan apa yang sudah dimiliki secara formal oleh guru selama ia belajar mengenai materi yang telah diberikan kepadanya (Kartono, 1990: 117). Apabila dilihat dari proses dan hasil tindakan, instrumen yang digunakan adalah valid karena telah terjadi proses pengembangan kemampuan musikalitas guru di TK Panti Dewi. 


\section{HASIL DAN PEMBAHASAN}

\section{Tahap pra-penelitian}

Pada tahap ini diawali dengan observasi atau pengamatan terhadap para guru TK dalam melaksanakan pembelajaran. Seperti yang telah ditetapkan pada jadwal kegiatan akademik, setiap Senin pukul 07.30 - 08.00 WIB diadakan upacara bendera. Selain mendampingi masingmasing kelas, ada guru yang mendikte anak didik sebagai protokol, pemimpin upacara dan pembaca Pancasila, mengiringi lagu Indonesia Raya, Mengheningkan Cipta dan Lagu wajib nasional atau lagu anak, serta mendampingi tiga orang anak didik yang mengibarkan bendera merah putih.

Saat menyanyikan lagu, semua guru bernyanyi untuk memberi contoh kepada para anak didik dan seorang guru bertugas mengiringi menggunakan keyboard. Hal yang menarik terjadi disini adalah guru mengiringi dengan tempo yang cepat, intro lagu yang tidak sesuai, nada dasar terlalu tinggi dan adakalanya terlalu rendah, serta penggunaan akord yang kurang harmonis. Keadaan seperti ini dianggap biasa saja oleh para guru. Bagi para guru, respon anak didik untuk ikut bernyanyi dirasa sudah cukup sebagai salah satu indikator perkembangan anak didik di sekolah.
Demikian halnya di Selasa, Rabu, dan Kamis, ketika sekolah mengawali kegiatan belajar dengan berdoa dan bernyanyi sesuai dengan tema pembelajaran hari tersebut. Sebelum masuk ke dalam kelas, anak didik berbaris di depan pintu sambil menyanyikan lagu seperti yang tertulis pada gambar 1 .

Pada waktu menyanyikan lagu tersebut, guru dan anak didik bertepuk tangan. Hanya saja saat diamati, setiap kelas menyanyikan dengan tempo yang berbeda-beda. Semakin cepat tempo bernyanyi, mereka akan semakin cepat masuk ke dalam kelas. Tidak berbeda pula kondisinya menjelang pulang sekolah. Anak didik diajak bernyanyi lagu penutup pembelajaran dengan tanpa memperhatikan nada, irama serta tempo lagu.

Pada pelaksanaan pembelajaran, setelah selesai berdoa, guru mengajak anak didik untuk bernyanyi kembali sesuai tema pembelajaran masing-masing kelas. Ada kelas yang menyanyikan lagu tentang alam, hubungan sosial dan ada pula yang menyanyikan lagu wajib nasional. Para guru juga tidak begitu memperhatikan bagaimana ia seharusnya memberikan contoh bernyanyi dengan baik. Sementara itu, ada 10 orang mahasiswa dari Fakultas Ilmu Pendidikan jurusan Pendidikan

\section{NENG NENG NENG}

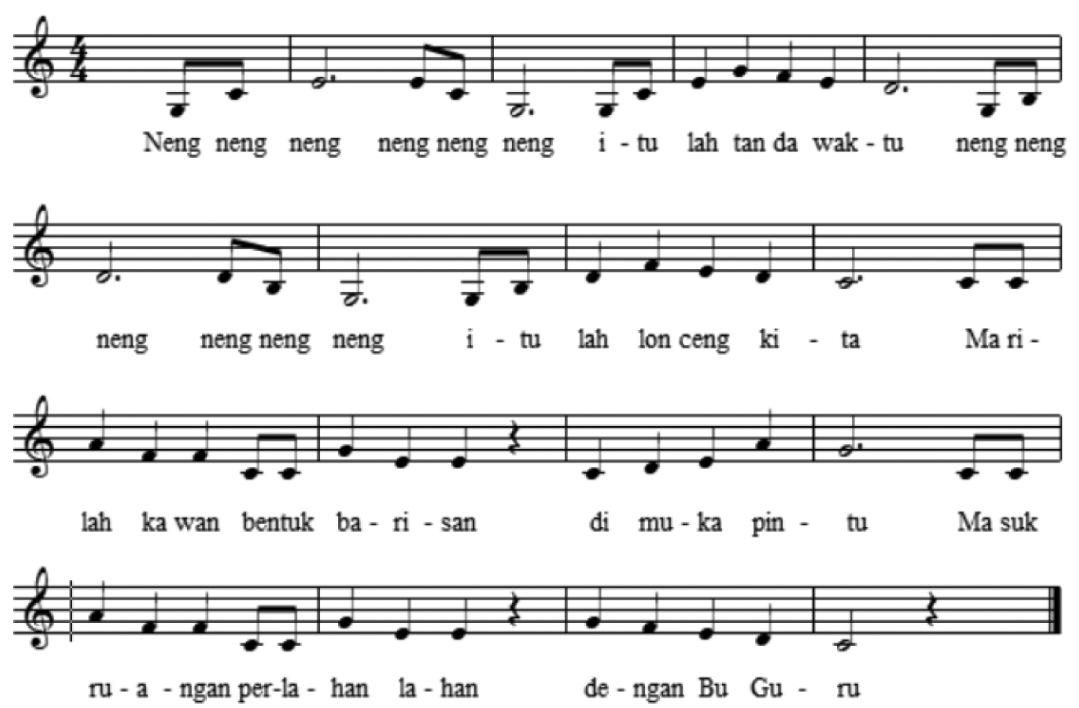

Gambar 1. Notasi lagu Neng Neng Neng (Transkripsi : Diah, Juli 2017) 
Usia Dini yang sedang menjalankan tugas praktik mengajar di TK Panti Dewi. Keadaan yang sama juga dilakukan oleh para mahasiswa. Mereka mengajak anak didik bernyanyi tanpa memperhatikan nada, irama, dan tempo lagu. Bahkan, mereka lebih mengutamakan "teriakan" untuk membuat para anak didik memperhatikan mereka.

Kegiatan pembelajaran yang berbeda lagi adalah kegiatan menari dan senam pagi. Setiap kelas ada jadwal menari tersendiri yang diajarkan oleh seorang guru yang memang berlatar belakang pendidikan seni tari, sedangkan kegiatan senam pagi dilakukan setiap hari Jumat pukul 07.30 - 08.00 WIB. Kedua kegiatan ini terfokus pada indikator motorik anak didik, meskipun di tengah-tengah iringan tari atau senam, anak didik diajak bernyanyi, tapi tetap tanpa nada dan irama yang seharusnya. Anak didik justru diajarkan untuk berteriak sambil beraktivitas seperti melangkah dan melompat. Gerakan anak didik juga tidak begitu diperhatikan apakah sesuai irama atau tidak. Hanya respon motorik saja yang jadi indikator penilaian perkembangan anak didik oleh guru.

\section{Proses Tindakan}

Dalam tahap penelitian ini, dilakukan dengan memberikan tindakan atas apa yang diamati selama tahap pra-penelitian. Ada 3 tindakan utama yang dilakukan yaitu:

a. melatih guru untuk memahami membaca notasi musik,

b. melatih guru untuk peka terhadap nada, irama dan tempo, dan

c. melatih guru untuk mengiringi lagu menggunakan keyboard.

Ketiga tindakan ini dilakukan secara bertahap, sesuai dengan kemampuan masingmasing guru dan secara individual menggunakan metode demonstrasi dan drill.

a. Melatih guru untuk memahami membaca notasi musik

Pada awal pertemuan, guru diberi materi tentang notasi musik berupa notasi angka dan notasi balok. Mereka diajarkan memahami nilai nada dan ketukan yang ada pada notasi. Kemudian dalam paranada mereka dilatih membaca dan menyebutkan dengan huruf nadanada, kemudian menyanyikan dan membunyikan nada sesuai dengan yang tertulis.

Setelah dikenalkan dengan nama nada, mereka berlatih ritmis sesuai ketukan dan nilai nada. Selanjutnya guru-guru diberikan materi dalam bentuk etude, yaitu metode khusus dalam pelajaran vokal. Hal ini dilatih secara berulangulang sampai guru dapat memahami nama nada sekaligus bunyinya.

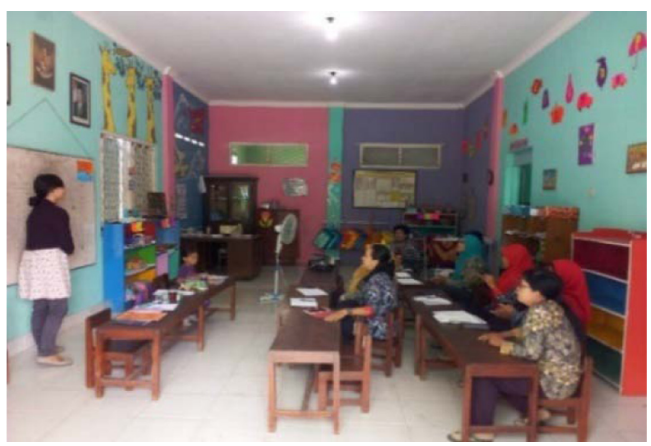

Foto 1. Peneliti menjelaskan membaca membaca notasi balok (Dok : Diah, Agustus 2017)

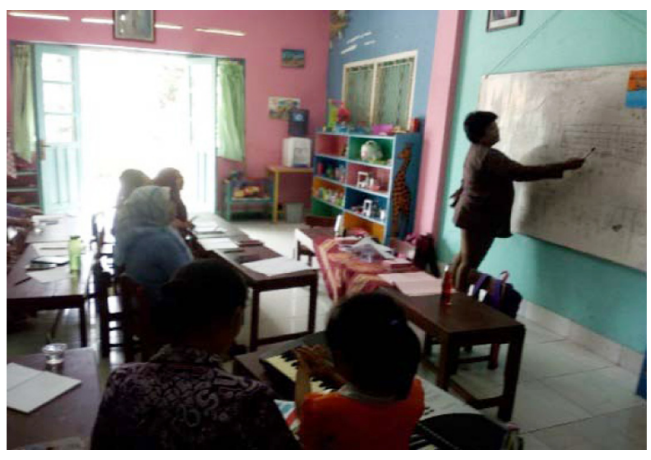

Foto 2. Seorang Guru mempraktikkan notasi balok (Dok : Diah, Agustus 2017)

b. Melatih guru untuk peka terhadap nada, irama, dan tempo

Sebagai lanjutan dari latihan sebelumnya, dengan menggunakan media keyboard, guru dilatih untuk mendengarkan nada-nada yang dimainkan pada keyboard. Para guru menirukan bunyi nada dengan suara masing-masing, dan setelah terbentuk "jalinan" melodi, guru diminta untuk menyanyikan nada-nada tersebut dengan benar dan tidak "fals". Kegiatan ini dilakukan 
secara berulang-ulang dengan metode drill agar guru memahami bunyi nada dengan baik.

Masih dengan materi etude Concone Op.9 No. 1, guru dilatih untuk memahami irama lagu. Dibantu dengan iringan keyboard, guru mendengarkan contoh irama yang diberikan, kemudian secara bersama-sama menyanyikan nada dan melodi dari awal sampai akhir mengikuti irama yang diberikan. Pada saat berlatih dalam kelompok, guru dilatih kepekaan dalam menentukan tempo, agar tidak terlalu cepat atau terlalu lambat, sehingga istilah tempo seperti moderato dipraktikkan oleh guru, juga dengan lagu model yaitu Pemandangan, Serumpun Padi, Suwe Ora Jamu, Sarinande dan Gundul-Gundul Pacul yang sudah dipersiapkan. Bersamaan dengan latihan tempo, guru juga dilatih bagaimana menyanyikan lagu dengan frasering, intonasi, dan artikulasi yang benar. Untuk mengecek apakah guru sudah benar dalam intonasi, frasering dan artikulasi, peneliti memberikan treatment secara individual. Khusus lagu Gundul-Gundul Pacul, para guru juga diperkenalkan dengan model bernyanyi kanon atau bersahut-sahutan. Di sini terlihat bagaimana para guru pada akhirnya dapat bernyanyi dengan "kompak" yaitu dalam kesatuan tempo dan irama.

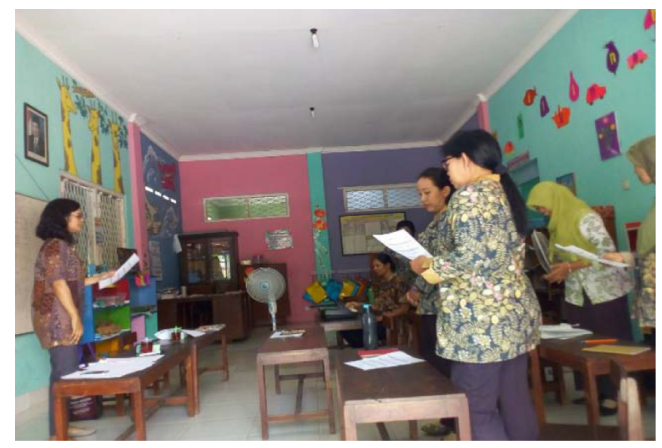

Foto 3. Peneliti melatih kepekaan nada dan melodi pada para Guru (Dok : Diah, Agustus 2017)

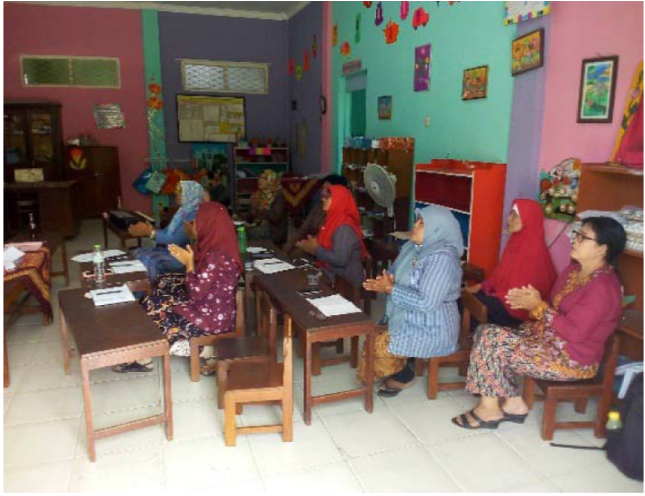

Foto 4. Para guru berlatih kepekaan irama dan tempo dengan tepuk tangan (Dok : Diah, Agustus 2017)

c. Melatih guru untuk mengiringi lagu menggunakan keyboard

Kegiatan ini adalah kegiatan yang paling sulit dilakukan. Para guru dilatih secara individual dalam 3 pertemuan setiap minggunya selama 1,5 jam dan wajib mempraktikkannya pada saat upacara bendera setiap hari Senin. Dalam hal ini, guru harus sangat sabar terhadap dirinya sendiri, karena selama ini mereka belum pernah memainkan alat musik keyboard terlebih lagi harus mengiringi. Tahap yang pertama, guru harus menguasai melodi pada lagu. Selanjutnya guru harus menghafal posisi nada yang ada pada keyboard dan bunyi nada yang dihasilkan. Melodi pada lagu tersebut kemudian dimainkan dengan tangan kanan. Tahap yang kedua, guru harus menghafal akord dan posisinya pada keyboard untuk dimainkan dengan tangan kiri. Tahap akhir adalah guru memainkan dengan dua tangan dan untuk lebih memudahkan prosesnya, guru harus menghafal semua hal yang ada pada lagu tersebut.

Lagu yang dimainkan adalah Lagu Indonesia Raya, Mengheningkan Cipta, Bendera Merah Putih, Satu Nusa Satu Bangsa, Ibu Kita Kartini, Kasih Ibu, Mars TK Panti Dewi, Kodok Ngorek, Pelangi dan Lihat Kebunku. Masing-masing guru mempersiapkan satu lagu yang dimainkan pada saat upacara secara bergiliran. Pada kegiatan ini mereka antusias untuk saling mengajari dan memperhatikan bila salah satu guru ada yang tidak bisa. Adakalanya pula dengan keyboard lebih dari satu, mereka saling mendengarkan 
dan memberi contoh yang benar ketika ada guru yang salah saat menekan tuts pada keyboard baik itu melodi ataupun akord.

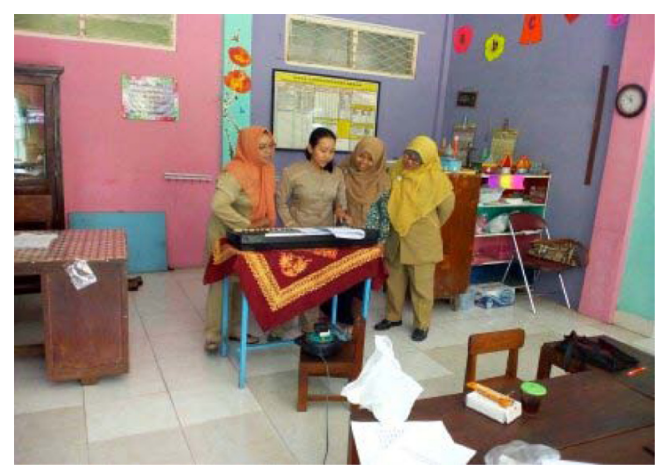

Foto 5. Seorang guru mempraktikkan materi iringan dan guru lainnya memperhatikan (Dok : Diah, September 2017)

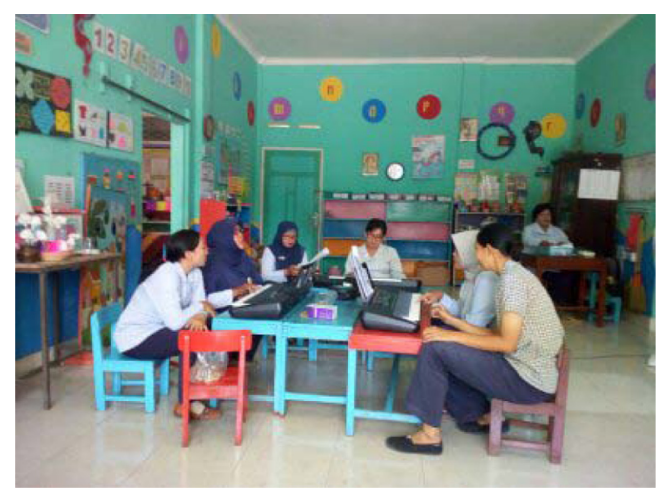

Foto 6. Peneliti melatih materi iringan sekaligus dialog dengan guru Dok : Ririn, September 2017)

\section{Penilaian dan Hasil}

a. Penilaian bernyanyi

Penilaian bernyanyi dilaksanakan pada akhir penelitian. Hal ini dilakukan dengan mengamati perkembangan musikalitas guru saat memberikan contoh bernyanyi pada anak didik TK, baik saat upacara ataupun di di dalam kelas. Penilaian ini meliputi penilaian atas kemampuan dasar Untuk penilaian secara khusus para guru diberi materi satu etude Concone Op.9 No 3 yang wajib dinyanyikan, dan lagu pilihan yang dinyanyikan salah satu yaitu Pemandangan atau Serumpun Padi. Untuk etude, masih terdapat beberapa kesalahan pada waktu menyanyikan, karena partitur dalam bentuk notasi balok. Kesalahan terjadi karena konsentrasi guru yang terpecah saat menyanyikan nada sekaligus mendengarkan iringan. Walaupun demikian, para guru tetap antusias menyanyi sampai dengan selesai dan setelah itu disambut tepuk tangan oleh guru-guru yang lain. Kemampuan musikalitas guru-guru dalam bernyanyi memperoleh nilai rata-rata $\mathbf{7 4 , 7}$ dan dalam kategori Baik.

\section{b. Penilaian Mengiringi}

Kegiatan pengembangan kemampuan musikalitas guru di TK Panti Dewi diakhiri dengan penilaian. Untuk mengiringi menggunakan keyboard, dilakukan penilaian pada setiap hari Senin, saat guru mendapat giliran mengiringi pada waktu upacara bendera. Masing-masing guru mengalami tingkat kesulitan yang berbeda-beda. Nilai rata-rata pada latihan mengiringi adalah 71,03 dengan kategori Baik. Pada hari-hari latihan, terutama hari Sabtu yang memang khusus persiapan untuk upacara, hampir semua guru dapat mengiringi dengan baik. Mereka menggunakan metode menghafalkan lagu, baik melodi ataupun akord. Adakalanya dibantu oleh beberapa guru dengan bernyanyi, sehingga tempo dan irama dapat berjalan sesuai dengan kaidah aturannya. Hanya saja, karena faktor psikologis, grogi atau nervous yang "menyelimuti" guru saat mengiringi dihadapan anak-anak dan para orang tua yang menunggu, membuat guru tersebut menjadi "kacau" dalam mengiringi. Tiba-tiba mereka lupa melodi, kemudian, akord dan saat kembali lagi ke intro serta salah menekaan tuts keyboard. Meskipun demikian, ada guru yang selalu ingin mencoba lagi untuk mengiringi, kemampuan musikalitasnya bisa dikatakan makin meningkat.

Dengan melihat perkembangan selama pelatihan, ada proses peningkatan atau perkembangan guru-guru TK dalam kemampuan musikalitas. Dari hasil wawancara, selama ini pengenalan tentang musik masih kurang karena hanya mendapat modal saat guru tersebut menempuh pendidikan di Sekolah Pendidikan Guru. Demikian pula ada guru yang menempuh pendidikan di konsentrasi Bimbingan Konseling, sehingga pengetahuan musik yang ada sangat 
Tabel 1. Hasil Penilaian Materi Bernyanyi

\begin{tabular}{llcccccc}
\hline \multirow{2}{*}{ No Nama } & \multicolumn{3}{c}{ Kemampuan Dasar } & \multicolumn{3}{c}{ Kemampuan Bernyanyi } \\
\cline { 3 - 7 } & & Nada & Ritmis & Tempo & Artikulasi & Intonasi & Frasering \\
\hline 1 & Praptini, S.Pd & 78 & 80 & 70 & 75 & 70 & 70 \\
2 & Kartinem, S.Pd., AUD & 82 & 78 & 72 & 75 & 75 & 70 \\
3 & Rutwantiasih, S.Pd & 78 & 75 & 75 & 73 & 74 & 78 \\
4 & Sri Sulistyowati, S.Pd & 78 & 80 & 70 & 73 & 78 & 75 \\
5 & Christina Janti Rosari, S.Pd., AUD & 85 & 87 & 75 & 84 & 85 & 83 \\
6 & Dra. Esthi Rahayu Mumpuni & 80 & 78 & 68 & 82 & 78 & 75 \\
7 & Supartiningsih & 65 & 70 & 63 & 63 & 60 & 60 \\
8 & Feri Tyas Maharani, S.Pd & 80 & 80 & 78 & 80 & 78 & 75 \\
9 & Deni Astuti, S.Pd & 78 & 80 & 75 & 75 & 75 & 73 \\
10 & Erri Kurnia Kusumaningtyas & 80 & 80 & 75 & 78 & 77 & 75 \\
\hline & Jumlah & 784 & 778 & 721 & 758 & 750 & 734 \\
\hline & Rata - rata & \multicolumn{7}{c}{76,1} & & & 74,7 & \\
\hline
\end{tabular}

Tabel 2. Hasil Penilaian Materi Mengiringi

\begin{tabular}{llcccccc}
\hline \multirow{2}{*}{ No Nama } & & \multicolumn{3}{c}{ Kemampuan Dasar } & \multicolumn{3}{c}{ Kemampuan Mengiringi } \\
\cline { 3 - 7 } & Nada & Ritmis & Tempo & $\begin{array}{c}\text { Harmoni } \\
\text { akord }\end{array}$ & Irama & $\begin{array}{c}\text { Tangga } \\
\text { nada }\end{array}$ \\
\hline 1 & Praptini, S.Pd & 68 & 60 & 65 & 62 & 63 & 60 \\
2 & Kartinem, S.Pd., AUD & 73 & 70 & 71 & 70 & 68 & 60 \\
3 & Rutwantiasih, S.Pd & 82 & 80 & 80 & 76 & 70 & 70 \\
4 & Sri Sulistyowati, S.Pd & 78 & 70 & 73 & 70 & 70 & 68 \\
5 & Christina Janti Rosari, S.Pd., AUD & 83 & 87 & 88 & 82 & 82 & 82 \\
6 & Dra. Esthi Rahayu Mumpuni & 78 & 70 & 70 & 80 & 68 & 68 \\
7 & Supartiningsih & 70 & 67 & 65 & 60 & 70 & 65 \\
8 & Feri Tyas Maharani, S.Pd & 81 & 81 & 80 & 76 & 75 & 70 \\
9 & Deni Astuti, S.Pd & 80 & 80 & 80 & 76 & 75 & 70 \\
10 & Erri Kurnia Kusumaningtyas & 80 & 82 & 82 & 78 & 77 & 70 \\
\hline & Jumlah & 773 & 747 & 754 & 730 & 718 & 683 \\
\hline & Rata - rata & \multicolumn{7}{c}{75,8} & & & 71,03 & \\
\hline
\end{tabular}

minim sekali. Hanya karena "senang" maka pengalaman musik tersebut dapat "digali" oleh peneliti. Selama proses tindakan, guruguru TK ini sangat antusias mengikuti semua tahapan pelatihan. Bahkan ada yang sama sekali memainkan alat musik, tetapi karena senang dan tertarik, maka saat diberikan pelatihan keyboard, meski sering lupa posisi, namun tetap berusaha untuk dapat bermain mengiringi saat bertugas di upacara bendera.

Pada waktu di dalam kelas, guru mengajarkan berbagai nyanyian sesuai tema pelajaran hari itu. Seperti lagu Pemandangan yang juga digunakan sebagai materi penilaian, adalah salah satu yang yang diajarkan di kelas, bahkan lagu ini diaransmen juga oleh pelatih drumband untuk mengikuti perlombaan. Pada tema pelajaran tentang keluarga, lagu Kasih Ibu dinyanyikan di setiap kelas dan saat upacara bendera. Oleh karena frekuensi lagu yang sering dinyanyikan bersama anak didik, semakin lama pembawaan lagu tersebut oleh guru semakin bagus.

Bagi guru-guru ada perbedaan secara psikologis pada saat materi pelatihan digunakan untuk mengajar di kelas dan latihan individual, dengan materi yang sama diujikan atau dinilai secara individu. Para guru lebih rileks saat di dalam kelas bersama anak-anak dan mengajarkan lagu secara artikulasi, intonasi dan frasering adalah benar dan baik, namun saat diujikan 
tersendiri, konsentrasi para guru menjadi tidak penuh dan banyak terdapat kesalahan. Latihan mengiringi pun demikian, saat didampingi, para guru bisa lancar bermain keyboard dan hafal dengan lagu yang menjadi tugasnya. Para guru juga secara individu berlatih di rumah, bahkan ada guru yang berusaha membeli alat musik keyboard agar dapat latihan mengiringi di rumah. Berbagai cara memang dilakukan oleh para guru, dengan memberi tanda pada keyboardnya di rumah, tuts apa yang harus ditekan sehingga mereka dapat menghafal posisi dan memainkannya dengan baik. Hanya saja saat upacara, keyboard yang digunakan tidak boleh diberi tanda apapun, sehingga hal itulah yang membuat para guru menjadi tidak percaya diri.

\section{KESIMPULAN}

Dari hasil penelitian ini disimpulkan bahwa kemampuan musikalitas guru di TK Panti Dewi semakin berkembang. Hal ini tampak pada hasil penilaian kemampuan dasar untuk materi bernyanyi dengan komponen artikulasi, intonasi dan ritmis berada dalam kategori baik yaitu 76,1 dan 74,7 . Kategori baik juga terlihat pada nilai kemampuan dasar untuk mengiringi dengan komponen harmoni akord, irama, dan tangga nada yaitu 75,8 dan 71,03 . Dengan demikian penelitian tindakan yang dilakukan dengan cara melatih guru untuk memahami membaca notasi musik, melatih guru untuk peka terhadap nada, irama dan tempo serta melatih guru untuk mengiringi lagu menggunakan keyboard, telah berhasil membantu guru di TK Panti Dewi dalam mengembangkan dan meningkatkan kemampuan musikalitas.

\section{DAFTAR PUSTAKA}

Amir, M.Taufiq. 2009. Inovasi Pendidikan Melalui Problem Based Learning: Bagaimana Pendidik Memberdayakan Pemelajar di Era Pengetahuan. Jakarta: Kencana.
Arikunto, Suharsimi. 2006. Prosedur Penelitian Suatu Pendekatan Praktik. Jakarta: PT Rineka Cipta.

Banoe, Pono, Dr. 2003. Kamus Musik. Jakarta: PT Indeks.

Banoe, Pono, Dr. 2013. Metode Kelas Musik. Yogyakarta: Penerbit Kanisius.

Hallam dan Prince V. 2003. Conceptions of Musical Ability. Research Studies in Music Education 20: 2-22.

Kartono, Kartini, Dr. 1990. Pengantar Metodologi Riset Sosial. Bandung: CV Mandar Maju.

Madya, Suwarsih. 1994. Seri Metodologi Penelitian. Panduan penelitian Tindakan. Yogyakarta: Lembaga Penelitian IKIP Yogyakarta.

Miller, Hugh. (Tanpa Tahun). Pengantar Apresiasi Musik. Terjemahan: Triyono Bramantyo P.S., Yogyakarta: ISI. Judul Asli: An Introduction to Music a Guide to Good Listening. 1991.

Müllensiefen D, Gingras B, Musil J, Stewart L. 2014. "The Musicality of Non-Musicians: An Index for Assessing Musical Sophistication in the General Population". PLoS One: Open Acces Journal, v. 9 (2). Diunduh pada 21 Juni 2017, dari https://www.ncbi.nlm. nih.gov/pmc/articles/PMC3935919.

Sanjaya, Wina. 2013. Strategi Pembelajaran. Jakarta : PT Raja Grafindo Persada.

Sugihartono, dkk. 2007. Psikologi Pendidikan. Yogyakarta : UNY Press.

Suryabrata B.A.,M.A., Ed.S., Ph.D., Drs. Sumadi, 2013. Metodologi Penelitian. Jakarta: PT Raja Grafindo Persada.

Undang-Undang RI 2005 No. 14, Guru dan Dosen. 